Canadian Science Publishing

Canadian Journal of Earth Sciences Revue canadienne des sciences de la Terre

\title{
Unusual preservation of the trace fossil Conostichus in middle Silurian carbonate facies of Indiana, USA
}

\begin{tabular}{|r|l|}
\hline Journal: & Canadian Journal of Earth Sciences \\
\hline Manuscript ID & cjes-2015-0198.R1 \\
\hline Manuscript Type: & Article \\
\hline Date Submitted by the Author: & 14-Mar-2016 \\
\hline Complete List of Authors: & $\begin{array}{l}\text { Thomka, James R.; University of Akron, Geosciences } \\
\text { Bantel, Thomas E.; Dry Dredgers } \\
\text { Tomin, Marissa J.; University of Akron, Geosciences }\end{array}$ \\
\hline Keyword: & ichnology, Wenlock, trace fossil taphonomy, $<$ i $>$ Conostichus $</$ i $>$ \\
\hline
\end{tabular}

SCHOLARONE ${ }^{\mathrm{M}}$

Manuscripts 
1 Unusual preservation of the trace fossil Conostichus in middle Silurian carbonate facies of

2 Indiana, USA

3

4 James R. Thomka ${ }^{1 *}$, Thomas E. Bantel ${ }^{2}$, and Marissa J. Tomin ${ }^{1}$

5

$6{ }^{1}$ Department of Geosciences, University of Akron, Akron, Ohio 44325, USA;

7 jthomka@uakron.edu,mjt70@zips.uakron.edu

8

$9 \quad 2$ Dry Dredgers, P.O. Box 210013, Cincinnati, Ohio 45221, USA; tebantel@cinci.rr.com

10

11 *Corresponding author (J. R. Thomka)

12 Department of Geosciences

13114 Crouse Hall

14 University of Akron

15 Akron, Ohio 44325, USA

16 E-mail: jthomka@uakron.edu

17 Telephone: +1-630-935-2983

18 Fax: 330-972-7611

19

20

21

22

23 
24 Unusual preservation of the trace fossil Conostichus in middle Silurian carbonate facies of

\section{Indiana, USA}

27 James R. Thomka, Thomas E. Bantel, and Marissa J. Tomin

29 Abstract: The long-ranging, plug-shaped ichnofossil Conostichus, attributed to solitary

30 polypoid cnidarians, is most commonly described in the Paleozoic from fine-grained siliciclastic

31 sediments, with few descriptions from carbonate settings. The few described examples of

32 putative Conostichus preserved in carbonate sedimentary rocks of Paleozoic age are essentially

33 conical masses lacking recognizable external radial or longitudinal structures. Herein, we

34 describe the occurrence of well-preserved examples of this ichnogenus within middle Silurian

35 (Wenlock: Sheinwooodian) carbonate sedimentary rocks of the Massie Formation from

36 southeastern Indiana, USA. These specimens represent isolated apical discs of Conostichus with

37 prominent radiating physal impressions displaying duodecimal symmetry. Interestingly, well-

38 preserved specimens co-occur with relatively poorly preserved (“typical carbonate") specimens.

39 The factors responsible for this unusual taphonomic state are unclear, but the most likely

40 explanation is that exceptionally preserved specimens represent burrows that were somehow

41 infilled, at least in their apical terminations, with fine-grained carbonate sediment, enhancing

42 preservational fidelity. In contrast, other burrows had their apical regions passively filled with

43 larger carbonate particles that could not preserve fine details. This occurrence indicates that

44 early Paleozoic carbonate sediments are capable of preserving Conostichus, and potentially other

45 ichnofossils, in similar modes to later Paleozoic siliciclastic deposits.

46 KEYWORDS: ichnology, Wenlock, trace fossil taphonomy, Conostichus 


\section{Introduction}

Conical sedimentary structures of both biotic and abiotic origin are common throughout the Phanerozoic stratigraphic record (Buck and Goldring 2003; Joeckel 2008). As thoroughly reviewed by Pemberton et al. (1988), most biogenically generated sedimentary structures characterized by a conical or plug-like shape can be classified as the common ichnogenera Conostichus, Bergaueria, Conichnus, Dolopichnus, and Astropolichnus; additional potentially conical ichnogenera include Monocraterion, Rosselia, Lingulichnus, and Pentichnus. Study of these and related structures poses a unique suite of challenges, including issues that arise from preservation of material that does not permit ready identification, differentiation, or interpretation of ichnotaxa. The relatively common ichnogenus Conostichus exemplifies this problem, as differentially preserved specimens may be misidentified (e.g., identified as

Bergaueria; see examples described in Pemberton et al. 1988) or go unrecognized as trace fossils (e.g., viewed as body fossils; Branson 1961, 1962).

Although Conostichus has been discovered in sedimentary units as old as Upper Cambrian (Mangáno et al. 1996; Poiré et al. 2003), this ichnogenus was originally described from, and has been most commonly reported from, Upper Carboniferous (Pennsylvanian) strata of eastern and midcontinental USA (Lesquereux 1876; Pemberton et al. 1988). Specimens in these settings are preserved within siliciclastic deposits representing paralic to shallow marine environments (e.g., Lesquereux 1876, 1883; Marple 1956; Branson 1960, 1961, 1962;

Pfefferkorn 1971; Hakes 1976; Miller and Knox 1985; Martino 1989; Greb and Chestnut 1994), which is true for Conostichus outside of the USA as well (e.g., Seilacher 1983; Mangáno et al. 1996). Traces from these units are preserved via infilling by fine-grained sediments (Pfefferkorn 1971), resulting in casting of such delicate features as radiating physal impressions, transverse 
70 constrictions, and rugose adjustment laminae (Pemberton et al. 1988). These features allowed

71 Conostichus to be readily recognized as the product of burrowing by solitary polypoid actinarian

72 cnidarians (Chamberlain 1971; Pemberton et al. 1988; Lech 2009; see also Shinn 1968; Frey

73 1970; Curran and Frey 1977).

74 Unfortunately, preservation of Conostichus in carbonate sedimentary rocks differs

75 markedly from those recovered from siliciclastic deposits, which include the type specimens of

76 all recognized ichnospecies (Pemberton et al. 1988). Carbonate sediments, particularly those

77 dominated by common Paleozoic bioclasts such as crinoid columnals (see Lowenstam 1957;

78 Ausich 1997), are commonly too coarse-grained to preserve fine morphological details.

79 Moreover, a high proportion of Paleozoic carbonates were subjected to diagenetic alteration that

80 obscured primary features of enclosed fossils. Hence, Conostichus has not been reported

81 commonly in early to middle Paleozoic carbonate strata, nor have assemblages been described in

82 detail, likely owing largely to taphonomic factors.

83 Here, we describe an occurrence of atypically preserved middle Silurian Conostichus

84 from argillaceous carbonate sediments. This assemblage is unique in that specimens display

85 morphological details typically observed only in siliciclastic environments and generally in

86 younger deposits. Exceptional preservation is evidently the result of unusual taphonomic

87 processes that permitted siliciclastic-style preservation in a carbonate environment.

\section{Locality, stratigraphic setting, and previous ichnological studies}

90 The specimens studied here were recovered from the New Point Stone quarry just east of

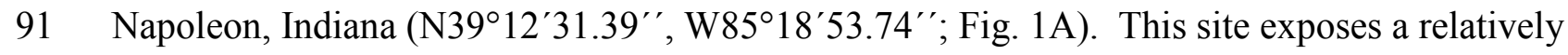

92 condensed, carbonate-dominated middle Silurian succession deposited in upper to middle ramp 
93 settings in close proximity to the proto-Cincinnati Arch (McLaughlin et al. 2008; Brett et al.

94 2012). The Silurian stratigraphy of this quarry, recently summarized by Thomka and Brett

$95(2015 a, 2015 b)$, comprises, in ascending order, the Aeronian "golden Brassfield" Formation (see

96 Brett et al. 2014), the Telychian-Sheinwoodian Osgood Formation, and the Sheinwoodian

97 Lewisburg, Massie, and Laurel formations (Fig. 1B).

98 Conostichus is present in the Massie Formation (Fig. 1B), which is composed of three

99 lithofacies: a basal skeletal packstone-grainstone, a thicker overlying interval of fossiliferous

100 siliciclastic mudstone with skeletal wackestone (biomicrite) interbeds, and an uppermost interval

101 of dense, poorly fossiliferous, silty packstones. The majority of burrows are found in the lower

102 decimeter of the mudstone lithofacies (Fig. 1B), present within the carbonate interbeds. The

103 carbonates that are interbedded within the siliciclastic mudstone lithofacies of the Massie

104 Formation have two origins: generally thinner, graded beds with sharp, erosional bases represent

105 storm beds, whereas more substantial, ungraded but also sharp-based beds with higher

106 proportions of micrite and a more concretionary texture represent sediment-starved small-scale

107 transgressive intervals. Specimens recovered from both types of these beds are generally

108 preserved hypichnially or endichnially, the latter typically having weathered free from

109 surrounding matrix in spoil piles or the exposed quarry floor. A smaller number of Conostichus

110 specimens was collected from the basal carbonate lithofacies of the Massie Formation (Fig. 1B);

111 these specimens are morphologically identical to those recovered from the mudstone lithofacies,

112 but are embedded tightly within the surrounding dense bioclastic material. For a more detailed

113 description of the Massie Formation basal carbonate lithofacies, see Thomka and Brett (2014,

114 2015a); for a more detailed description of the lower mudstone lithofacies, see Thomka and Brett

115 (2015b) and Thomka et al (2016). 
117 primarily on hard-substrate ichnofaunas, particularly parasitic embedment structures in

118 diploporite echinoderms (Paul 1971; Brett 1985; see also Frest et al. 1977, which does not

119 specifically mention localities bearing parasitized echinoderms) and Trypanites borings in large

120 crinoid pluricolumnals and calyxes (Thomka and Brett 2014, 2015b). Burrows described from

121 the lower Massie Formation consist of pre-omission firmground Thalassinoides from the basal

122 carbonate lithofacies (Thomka and Brett 2015a) and thin, meandering pascichnia (Gordia isp.?)

123 in areas surrounding microbiohermal buildups (Thomka and Brett 2015b). The current

124 description represents the first detailed study of softground trace fossils found within the 125 mudstone lithofacies of the Massie Formation.

\section{Preservation of Conostichus}

Specimens can be classified as belonging to one of two primary taphonomic categories:

129 those displaying carbonate-style preservation and those displaying siliciclastic-style preservation.

130 Carbonate-style preservation, shown in Figure 2, is characterized by a tapering, conical shape

131 with no discernable wall ornamentation (though some relatively well-preserved representatives

132 may display subtle, barely recognizable radial structures on the walls, as in Fig. 2B). Traces

133 preserved in this style vary considerably in size, with the smallest specimens being roughly the

134 same diameter as the exceptionally preserved specimens described below and the largest

135 specimens exceeding $5 \mathrm{~cm}$ in diameter at the widest end (Figs. 2A-B). Burrows that were cut

136 open to expose sedimentary infill consistently show a pattern of relatively coarse bioclastic

137 grains along the bottom and sides of the structure, with finer particles (smaller bioclasts,

138 siliciclastic mud, and micrite) in the interior (Fig. 2C). No semblance of laminae, chevron- 
139 shaped or otherwise (cf. Pfefferkorn 1971; Pemberton et al. 1988), are preserved within

140 specimens characterized by carbonate-style preservation (Fig. 2C).

141 Conostichus displaying siliciclastic-style preservation are more similar to specimens

142 figured in published literature (i.e., those typically reported from Carboniferous deposits; see

143 Pemberton et al. 1988). These retain physal impressions in the apical region, with or without

144 transverse constrictions and longitudinal ridges along the exterior wall of the burrow (Fig. 3C).

145 Although this mode of preservation has not previously been reported from carbonate settings

146 (see Fig. 2), a few specimens from the study site bear radiating, duodecimally symmetrical

147 physal impressions (Fig. 3A-B). Interestingly, all currently known specimens characterized by

148 retention of these seemingly delicate features are small $(\sim 1.5 \mathrm{~cm}$ in diameter) and short (less than

$1492 \mathrm{~cm}$ in height), with no recognizable tapering (Fig. 3A). There is no evidence of erosional

150 truncation of the upper portions of these burrows. Although it is theoretically possible that these

151 represent burrows that were shallowly emplaced, there is not a realistic mechanism that would

152 lead to preferential preservation of external features in shallow structures over deeper structures.

153 A better explanation is that these specimens represent isolated apical discs separated from the

154 upper portion of the burrow. No upper portions of incomplete Conostichus were discovered that

155 retain ornamentation; hence, it is unknown whether Conostichus displaying siliciclastic-style

156 preservation in the Massie Formation are capable of preserving other external features.

157 Specimens retaining physal impressions are composed entirely of fine-grained carbonate

158 sediment, with no component of macroscopic bioclastic particles (Fig. 3A). These traces were

159 too small and too valuable to be prepared for thin-section analysis, but examination under an

160 optical microscope suggests little to no dilution by siliciclastic particles. Hence, this occurrence

161 represents an unusual ichnotaphonomic juxtaposition, with carbonate sediments preserving 
162 Conostichus with readily altered or destroyed features.

163

164 Discussion

165

166

167

168

169

170

171

172

173 composition.

174

175

176

177

178

179

180

181 would have readily been incorporated into graded beds during episodes of increased current

182 velocity. Hence, the skeletal material comprising the "coarse-grained rim" of specimens

183 characterized by carbonate-style preservation (Fig. 2C) was probably introduced during high-

184 energy events. This is supported by the occurrence of Conostichus displaying carbonate-style 
185 preservation at the bases of storm beds.

186 Because of the relationship between storm events and carbonate-style preservation, event

187 sedimentation does not appear to be an absolute necessity for exceptional preservation of

188 Conostichus. The well-preserved specimens (i.e., those characterized by siliciclastic-style

189 preservation; Fig. 3A) may represent instances where Conostichus was passively infilled under

190 quiescent background conditions. Since the specimens displaying the most well-developed

191 siliciclastic-style preservation were recovered from spoil piles, it is uncertain but possible that

192 these were derived from the carbonate interbeds (i.e., those that are not storm beds) in the

193 mudstone lithofacies of the Massie Formation. Whether early diagenetic cementation of fine-

194 grained sediment also played a role in enhancing preservation is unclear, but may have

195 contributed to some degree in facilitating siliciclastic-style preservation.

196 Brett and Allison (1998, p. 322) suggested that the abundance of echinoderm ossicles in

197 putative Conostichus reflects disruption of buried, previously articulated skeletons during

198 burrowing, followed by concentration and reorientation of skeletal grains within the burrow.

199 This interpretation implies that the disparity in preservational styles observed in this study

200 reflects slightly differing behaviors by the burrowing cnidarian rather than purely depositional

201 processes. Although it is possible that ethological differences account for the preservational

202 variability among Conostichus from the lower Massie Formation, we see no evidence that the

203 "coarse-grained rim" represents the result of an active filling process (i.e., there is no true mantle

204 within these specimens). The absence of preferred orientations or preferred bioclast size and/or

205 shape, and the compositional variation from specimen to specimen is far more suggestive of a

206 passive physical process than an active biological process.

207 It is well established that taphonomic processes are key factors in controlling the 
208 perceived diversity and ichnotaxonomic identity of trace fossils (MacNaughton and Pickerill

209 2003; Savrda 2007). Moreover, an understanding of the underlying controls on variable trace

210 fossil preservation permits more accurate interpretation of the relative influence of taphonomic,

211 as opposed to ethologic, patterns that govern trace fossil diversity, abundance, and lithofacies

212 relationships (Archer 1984). The Silurian Conostichus assemblage described here represents an

213 illustrative case study of the significance of variable preservational histories in imparting

214 dramatically different physical properties to trace fossils recovered from a single stratigraphic

215 unit. This is significant not only in addressing how exceptionally well-preserved trace fossils

216 and more typical representatives of the same ichnotaxon can be documented from the same

217 interval, but also in understanding the major differences in ichnofossil preservational patterns

218 observed between siliciclastic and carbonate regimes.

220 Conclusions

221 Well-preserved specimens of the trace fossil Conostichus (i.e., those characterized by

222 distinct physal impressions) are present in carbonate sedimentary rocks within the middle

223 Silurian Massie Formation of southeastern Indiana, USA. This occurrence is unusual because

224 Conostichus in carbonates are generally lacking in any recognizable internal detail, being

225 characterized only by a conical shape and a homogeneous or crudely graded fill. The specimens

226 described here are more similar to "typical" Conostichus described from Upper Carboniferous

227 siliciclastic deposits, which preserve fine internal structures. The exact taphonomic factors that

228 led to siliciclastic-style preservation of Conostichus in carbonate sediments are not entirely clear,

229 but most likely involve instances where fine-grained carbonate particles, rather than coarser

230 bioclasts, infilled the bases of cavities. This led to casting of fine details of the apical region, 
231 potentially coupled with rapid cementation of sedimentary fill. Thus, this occurrence represents

232 a setting where early-middle Paleozoic carbonate sedimentary rocks were capable of preserving

233 Conostichus in a mode otherwise primarily encountered in siliciclastic deposits, including those

234 from which type ichnospecies have been described.

235

\section{Acknowledgments}

237 Funding for this research was provided by a Dry Dredgers Paul Sanders Award, a Dry

238 Dredgers Paleontological Research Award, and a Paleontological Society N. Gary Lane

239 Research Grant to JRT. The owners and management of the New Point Stone quarry in

240 Napoleon, Indiana graciously allowed access to the study site. Previous versions of this article

241 were improved by the constructive reviews provided by Stephen K. Donovan (Netherlands

242 Centre for Biodiversity) and an anonymous reviewer. This is a contribution to the International

243 Geoscience Programme (IGCP) Project No. 591 - The Early to Middle Paleozoic Revolution.

\section{References}

246 Archer, A.W. 1984. Preservational control of trace-fossil assemblages: Middle Mississippian

247 carbonates of south-central Indiana. Journal of Paleontology, 58: 285-297.

249 Ausich, W.I. 1997. Regional encrinites: A vanished lithofacies. In Paleontological Events:

250 Stratigraphic, Ecological, and Evolutionary Implications. Edited by Brett, C.E., and

251 Baird, G.C. Columbia University Press, New York. pp. 509-519.

253 Branson, C.C. 1960. Conostichus. Oklahoma Geology Notes, 20: 195-207. 
255 Branson, C.C. 1961. New records on the scyphomedusan Conostichus. Oklahoma Geology Notes, 21: 130-138.

Branson, C.C. 1962. Conostichus, a scyphomedusan index fossil. Oklahoma Geology Notes, 22: 251-253.

Brett, C.E. 1983. Sedimentology, facies and depositional environments of the Rochester Shale (Silurian; Wenlockian) in western New York and Ontario. Journal of Sedimentary Petrology, 53: 947-971.

Brett, C.E. 1985. Tremichnus: A new ichnogenus of circular-parabolic pits in fossil echinoderms. Journal of Paleontology, 59: 625-635.

Brett, C.E., and Allison, P.A. 1998. Paleontological approaches to the environmental interpretation of marine mudrocks. In Shales and Mudstones I: Basin Studies, Sedimentology, and Paleontology. Edited by Schieber, J., Zimmerle, W., and Sethi, P.S.

272

273 Brett, C.E., and Taylor, W.L. 1997. The Homocrinus beds: Silurian crinoid Lagerstätten of western New York and southern Ontario. In Paleontological Events: Stratigraphic, Ecological, and Evolutionary Implications. Edited by Brett, C.E., and Baird, G.C.

276 Columbia University Press, New York. pp. 181-223. 
278 Brett, C.E., Cramer, B.D., McLaughlin, P.I., Kleffner, M.A., Showers, W.J., and Thomka, J.R. 2012. Revised Telychian-Sheinwoodian (Silurian) stratigraphy of the Laurentian midcontinent: Building uniform nomenclature along the Cincinnati Arch. Bulletin of Geosciences, 87: 733-753.

Brett, C.E., Thomka, J.R., Sullivan, N.B., and McLaughlin, P.I. 2014. Anatomy of a compound sequence boundary: A basal Silurian karstic unconformity in the Cincinnati Arch region. GFF, 136: 42-47.

Buck, S.G., and Goldring, R. 2003. Conical sedimentary structures, trace fossils or not?

Chamberlain, C.K. 1971. Morphology and ethology of trace fossils from the Ouachita Mountains, southeast Oklahoma. Journal of Paleontology, 45: 212-246.

Curran, H.A., and Frey, R.W. 1977. Pleistocene trace fossils from North Carolina (U.S.A.), and

297 Frest, T.J., Mikulic, D.G., and Paul, C.R.C. 1977. New information on the Holocystites Fauna their Holocene analogues. In Trace Fossils 2. Edited by Crimes, T.P., and Harper, J.C. Seel House Press, Liverpool. pp. 139-162. (Diploporita) of the middle Silurian of Wisconsin, Illinois, and Indiana. Fieldiana: Geology, 35: 83-108. 
301 Frey, R.W. 1970. The Lebensspuren of some common marine invertebrates near Beaufort, North Carolina. II. Anemone burrows. Journal of Paleontology, 44: 308-311.

303

304 Greb, S.F., and Chestnut, D.R., Jr. 1994. Paleoecology of an estuarine sequence in the Breathitt Formation (Pennsylvanian), central Appalachian Basin. Palaios, 9: 388-402.

Hakes, W.G. 1976. Trace fossils and depositional environment of four clastic units, Upper 309 Pennsylvanian megacyclothems, northeast Kansas. University of Kansas Paleontological Contributions, 63: 1-46.

Joeckel, R.M. 2008. Enigmatic structures in an Upper Pennsylvanian (Kasimovian) marine limestone. Palaios, 23: 833-847.

Lech, R.R. 2009. Inner morphology of Palaeoanemone (Cnidaria: Actinaria): A burrowing

317 Lesquereux, L. 1876. Species of fossil marine plants from the Coal Measures. Indiana anemone of the Carboniferous of Argentina. Serie Correlación Geológica, 25: 27-36. Geological Survey Annual Reports, 7: 134-145. 
323 Lowenstam, H.A. 1957. Niagaran reefs in the Great Lakes area. In Treatise on Marine Ecology

324 and Paleoecology. Edited by Ladd, H.S. Geological Society of America Memoir 67. pp. $325 \quad 215-248$.

326

327 MacNaughton, R.B., and Pickerill, R.K. 2003. Taphonomy and taxonomy of trace fossils: A 328 commentary. Lethaia, 36: 66-70.

329

330 Mangáno, M.G., Buatois, L.A., and Acenolaza, G.F. 1996. Trace fossils and sedimentary facies from a Late Cambrian-Early Ordovician tide-dominated shelf (Santa Rosita Formation, northwest Argentina): Implications for ichnofacies models of shallow marine

Marple, M.F. 1956. On the fossil Conostichus. Ohio Journal of Science, 56: 29-30. successions. Ichnos, 5: 53-88.

McLaughlin, P.I., Cramer, B.D., Brett, C.E., and Kleffner, M.A. 2008. Silurian high-resolution stratigraphy on the Cincinnati Arch: Progress on recalibrating the layer-cake. In From the

Martino, R.L. 1989. Trace fossils from marginal marine facies of the Kanawha Formation (Middle Pennsylvanian), West Virginia. Journal of Paleontology, 63: 389-403. Cincinnati Arch to the Illinois Basin: Geological Field Excursions along the Ohio River Valley. Edited by Maria, A.H., and Counts, R.C. Geological Society of America Field 
346 Miller, M.F., and Knox, L.W. 1985. Biogenic structures and depositional environments of a Lower Pennsylvanian coal-bearing sequence, northern Cumberland Plateau, Tennessee, U.S.A. In Biogenic Structures: Their Use in Interpreting Depositional Environments. Edited by Curran, H.A. Society of Economic Paleontologists and Mineralogists Special Publication 35. pp. 67-98.

O’Brien, N.R., Brett, C.E., and Taylor, W.L. 1994. Microfabric and taphonomic analysis in determining sedimentary processes in marine mudstones: Example from Silurian of New

Paul, C.R.C. 1971. Revision of the Holocystites fauna (Diploporita) of North America. Fieldiana: York. Journal of Sedimentary Research, 64: 847-852.

Pemberton, S.G., Frey, R.W., and Bromley, R.G. 1988. The ichnotaxonomy of Conostichus and other plug-shaped ichnofossils. Canadian Journal of Earth Science, 25: 866-892. Geology, 26: 1-166.

Pfefferkorn, H.W. 1971. Note on Conostichus broadheadi Lesquereux (trace fossil: platform of the Balcarce Formation (Tandilia System, Argentina): Facies, trace fossils, palaeoenvironments and sequence stratigraphy. Geologica Acta, 1: 41-60. 
369 Savrda, C.E. 2007. Taphonomy of trace fossils. In Trace Fossils: Concepts, Problems, Prospects. Edited by Miller, W., III. Elsevier, Amsterdam. pp. 92-109.

372 Seilacher, A. 1983. Upper Paleozoic trace fossils from the Gilf Kebir-Abu Ras area in southwestern Egypt. Journal of African Earth Sciences, 1: 21-34.

Shinn, E.A. 1968. Burrowing in recent lime sediments of Florida and the Bahamas. Journal of Paleontology, 42: 878-894.

Thomka, J.R., and Brett, C.E. 2014. Taphonomy of diploporite (Echinodermata) holdfasts from a Silurian hardground, southeastern Indiana, United States: Palaeoecologic and stratigraphic significance. Geological Magazine, 151: 649-665.

Thomka, J.R., and Brett, C.E. 2015a. Paleoecology of pelmatozoan attachment structures from a

390 Thomka, J.R., Brett, C.E., Bantel, T.E., Young, A.L., and Bissett, D.L. 2016. Taphonomy of 
392 Indiana, USA: The Lower Silurian Massie Formation as an atypical Lagerstätte.

393 Palaeogeography, Palaeoclimatology, Palaeoecology, 443: 263-277.

394

395

396

397

398

399

400

401

402

403

404

405

406

407

408

409

410

411

412

413

414 
415 Fig. 1. Geographic and stratigraphic setting of Conostichus specimens studied. (A) Location of 416 the New Point Stone quarry, just east of the town of Napoleon in southeastern Indiana, USA.

417 Ripley County, within which the study site is located, is represented by the irregular polygon.

418 Modified from Thomka and Brett (2014a). (B) Photograph of the quarry wall with labeled

419 formation-scale stratigraphic units (lithostratigraphic nomenclature follows Brett et al. 2012).

420 Most specimens were recovered from the base of the mudstone lithofacies of the Massie

421 Formation, marked by the black stars; a smaller number of specimens was recovered from the 422 underlying carbonate lithofacies, marked by the white star. Scale bar $=1 \mathrm{~m}$.

424 Fig. 2. Examples of carbonate-style preservation of Conostichus, common to most Paleozoic 425 carbonate units, including the Massie Formation of southeastern Indiana. Note the absence of 426 physal impressions, transverse constrictions, and longitudinal ridges. (A) Typical, relatively

427 large specimen with a well-developed tapering form. (B) Specimen with faint radiating 428 structures, possibly corresponding to very minor radiating ridges. (C) Vertical cross-section 429 showing infill of burrows. Note that sedimentary fill can be roughly divided into two zones, a 430 coarse-grained rim $(c g r)$ and a finer-grained core $(f g c)$. The presence of this coarse-grained rim 431 seemingly precludes preservation of fine details in carbonate-style preservation of this 432 ichnogenus. All scale bars $=1 \mathrm{~cm}$.

434 Fig. 3. Unusually preserved Conostichus from carbonate interbeds within the lower mudstone 435 lithofacies of the Massie Formation of southeastern Indiana. (A) Exceptionally well-preserved 436 specimen displaying prominent radiating physal impressions. This is typical of siliciclastic-style 437 preservation and is otherwise not observed in carbonate units (compare with Figure 2). Scale bar 
$438=0.5 \mathrm{~cm}$. (B) Traced outline of the specimen in Fig. 3A with the twelve lobes labeled; this

439 demonstrates the duodecimal symmetry characteristic of this ichnogenus, but generally

440 documented only from siliciclastic-style preservation. (C) An example of typical siliciclastic-

441 style preservation, from a paralic deposit in the Pennsylvanian Breathitt Formation of eastern

442 Kentucky, USA. Note the presence of fine details not present on specimens in Figure 2. Also

443 note that the specimen in Figure 3A likely corresponds only to the terminal apical disc of this

444 specimen. Scale bar $=1 \mathrm{~cm}$. 


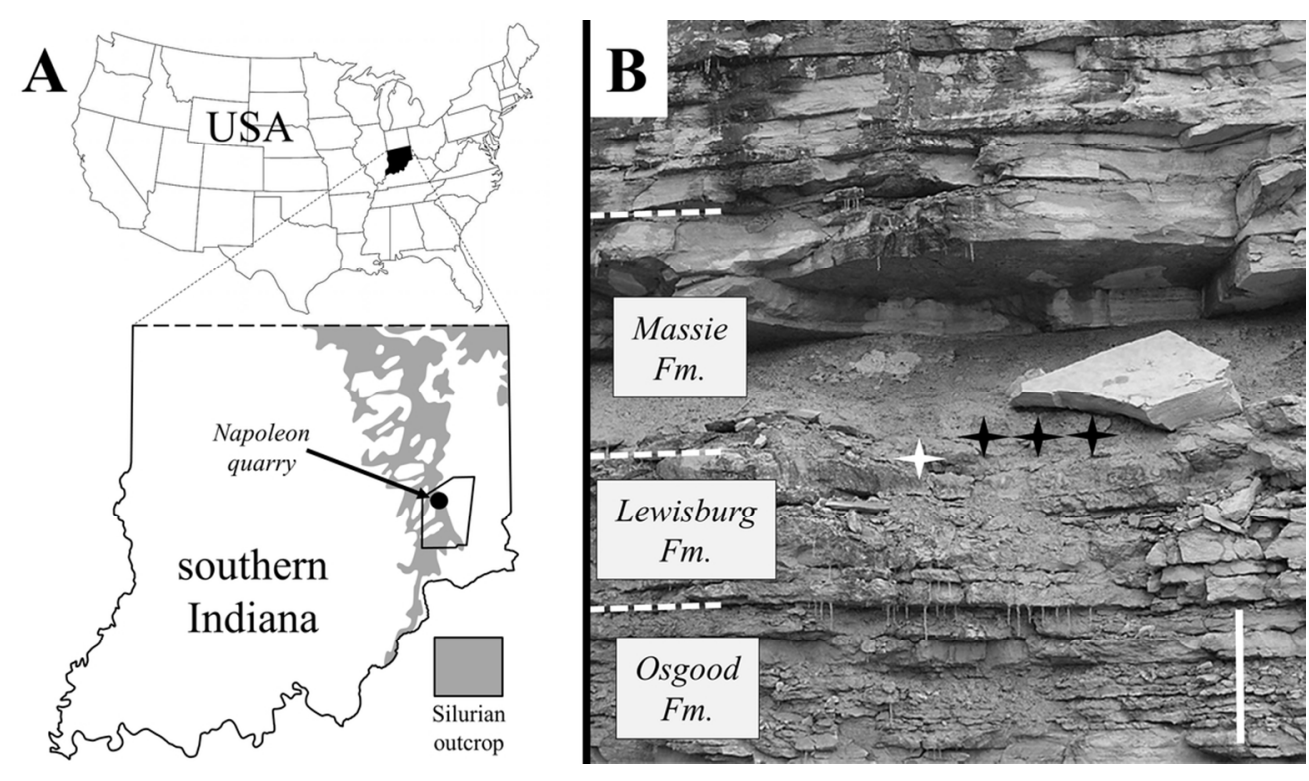

$101 \times 57 \mathrm{~mm}(300 \times 300$ DPI $)$ 

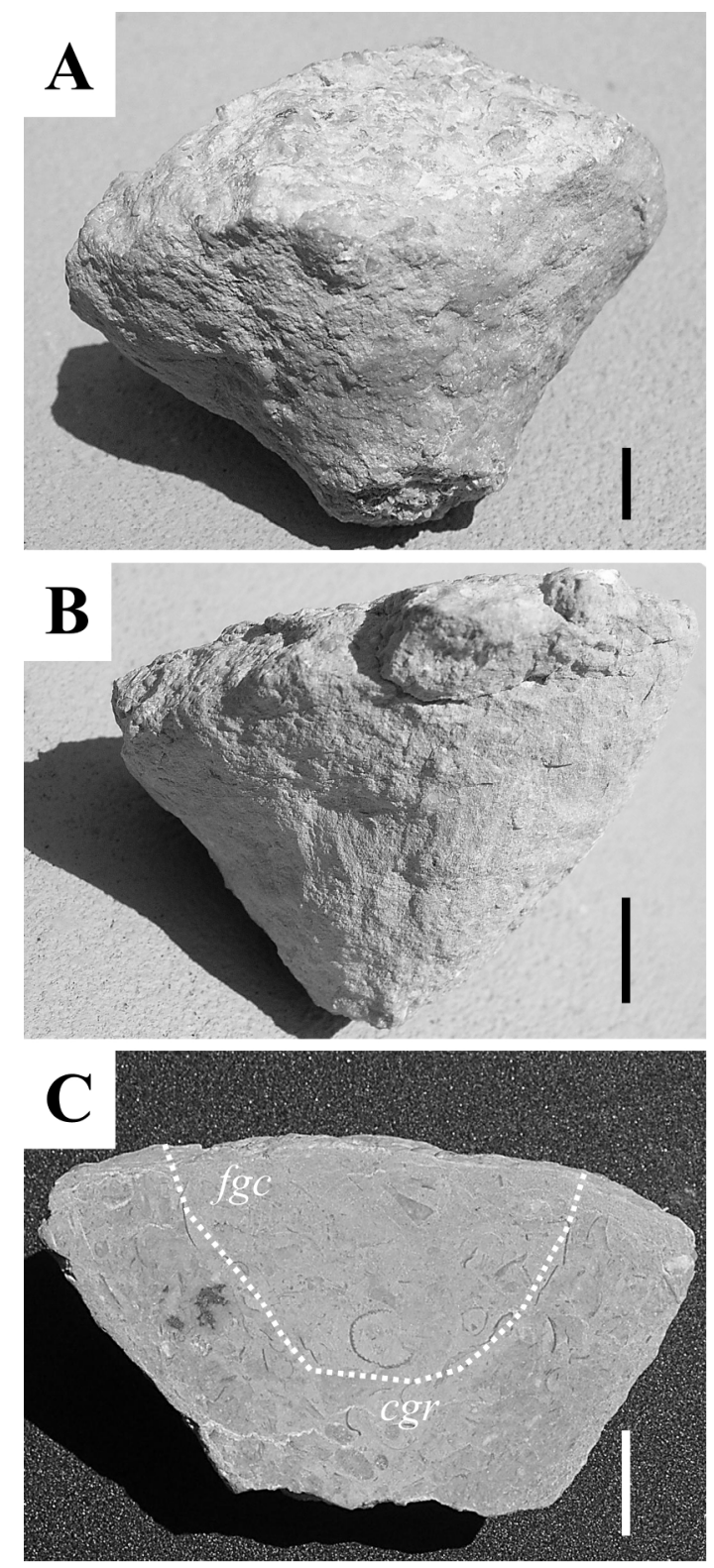

$195 \times 444 \mathrm{~mm}(300 \times 300$ DPI $)$ 


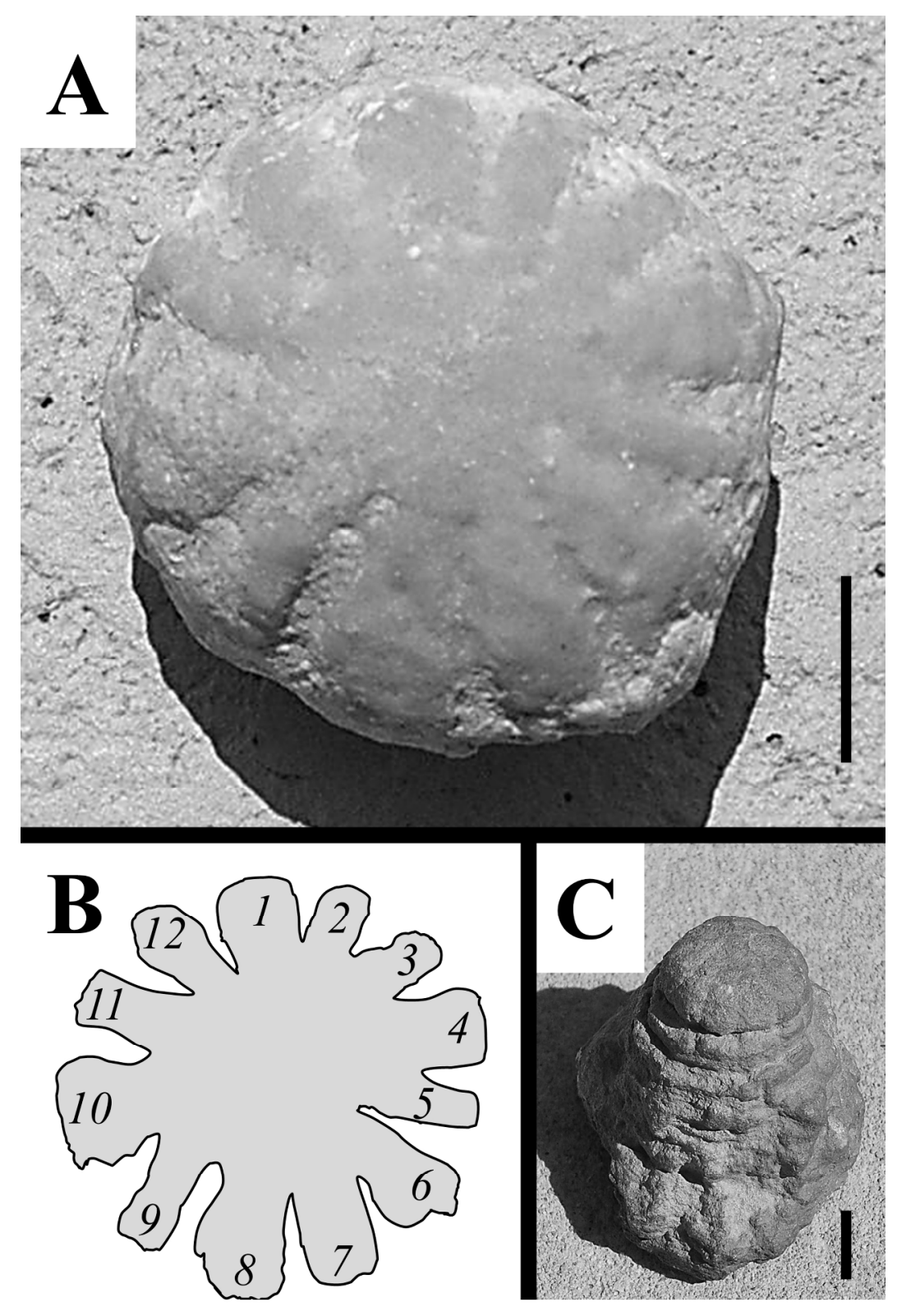

$127 \times 189 \mathrm{~mm}(600 \times 600 \mathrm{DPI})$ 